\title{
Does Darwall's Morality of Accountability Require Moral Realism? (And Would It Be Strengthened by Adding God to the Story?)
}

\section{Stephen Evans}

\section{check for} updates

Citation: Evans, C. Stephen. 2021. Does Darwall's Morality of Accountability Require Moral Realism? (And Would It Be Strengthened by Adding God to the Story?). Religions 12: 187. https:// doi.org/10.3390/rel12030187

Academic Editors: J. Caleb Clanton and Kraig Martin

Received: 25 January 2021 Accepted: 7 March 2021

Published: 11 March 2021

Publisher's Note: MDPI stays neutral with regard to jurisdictional claims in published maps and institutional affiliations.

Copyright: (C) 2021 by the author. Licensee MDPI, Basel, Switzerland. This article is an open access article distributed under the terms and conditions of the Creative Commons Attribution (CC BY) license (https:/ / creativecommons.org/licenses/by/ $4.0 /)$.
Department of Philosophy, Baylor University, One Bear Place, \#97273, Waco, TX 76798-7273, USA;

c_stephen_evans@baylor.edu

\begin{abstract}
Stephen Darwall has developed an account of moral obligations as grounded in "secondpersonal reasons," which was developed in conversation with early modern "theological voluntarists" who were divine command theorists. For Darwall, morality does not require accountability to God; humans as autonomous moral agents are the source of moral obligations. In this paper, I try to show that Darwall is vulnerable to some objections made against divine command theories. There are responses Darwall could make that have parallels to those given by divine command theorists. However, those responses require moral realism, while Darwall's project is often seen as being inspired by metaethical constructivism. Finally, I suggest that Darwall's view could be further strengthened by the addition of God to the story.
\end{abstract}

Keywords: accountability; Stephen Darwall; theological voluntarism; divine command theory; constructivism; second-personal reasons; Robert Adams

In the last two decades, Stephen Darwall has developed what he calls a "juridical account" of moral obligations. The account is inspired by themes in Fichte and Kant, but it is also developed in conversation with early modern "theological voluntarists," such as Pufendorf and Locke, who defended a divine command account of moral obligations. Like these early modern thinkers, Darwall wants to hold that moral obligations are grounded in the demands of persons, that moral obligations are linked to being accountable for such demands, and that persons can be held blameworthy when these obligations are not fulfilled. However, for Darwall, no divine commands are necessary for morality. Rather, the foundations of morality lie in a moral community of equal, autonomous human agents who hold each other accountable. ${ }^{1}$

In this paper, I raise the question as to whether the parallels between Darwall's view and a divine command theory might mean that Darwall's view is vulnerable to some of the objections, such as the Euthyphro problem, which are often raised against a divine command theory. I answer the question by comparing Darwall's view to a contemporary divine command theory, that of Robert Adams. It appears that someone might object to Darwall's view in ways that are similar to the manner in which Adams' divine command theory is often criticized. Such criticisms are not necessarily devastating, as can be seen by examining the way Adams himself responds. Darwall's view could be defended by making moves similar to those Adams makes. However, it appears that the responses would require Darwall to embrace a substantial form of moral realism, a view which is not a cost to Adams since he already accepts the existence of objective value. Such a response also seems possible for Darwall; at least it is logically consistent with his view. There is, however, a cost, in that part of the motivation for Darwall's view seems to lie

1 Gary Watson explicitly claims that Darwall's whole project can be read as a response to Elizabeth Anscombe's famous complaint against "modern moral philosophy." Anscombe says that the concept of moral obligation only makes sense if there is a lawgiver and urges contemporary philosophers to drop discussions of obligation in favor of virtues. Watson says, rightly in my view, that Darwall attempts to show that human persons can substitute for God and thus that God is not necessary to make sense of morality. See (Watson 2007). 
in a metaethical constructivism that grounds morality in human willing and activity. In conclusion, I suggest that Darwall's view would not only be strengthened by embracing moral realism but that it would be stronger still if God were brought back into the story. Moral obligations would then be grounded in actual demands (assuming God exists, admittedly a big assumption for many), not merely in the hypothetical demands of an idealized moral community.

\section{Darwall's Defense of a "Juridical" View of Moral Obligations}

Darwall has made an impressive case for the role of what he calls "second-personal reasons" as the basis of morality. ${ }^{2}$ The argument begins with a defense of a "juridical" view of moral obligations. On this view, a moral obligation is not simply an act one has a moral reason to do. Rather, moral obligations derive from claims or demands that persons make on each other:

If all this is correct, then the concept of moral obligation must differ from that of what moral reasons recommend, however categorical or overriding these reasons might be. What fills the gap ... is the concept of accountability and moral blame. Moral obligations are moral demands, and moral demands are whatever we are legitimately held to or answerable for, that is, where violations are blameworthy if the agent lacks a valid excuse. ${ }^{3}$

The plausibility of Darwall's view gains much of its force from examples of demands that individuals make on one another. His favorite example is someone standing on another person's foot. ${ }^{4}$ A utilitarian might well say that this is morally wrong just because it is an act that causes needless pain. However, even if this is so, the situation changes if the person whose foot is being stood upon makes a request to the offending party to move the foot. If the offender refuses to move the foot, then the act is wrong in a new way and for a new reason: a justified claim has been ignored and this shows a lack of respect for the person who has made the claim.

This seems perfectly right. In this case, there is an actual claimant and an actual claim. However, although Darwall wants to argue that morality is linked to being accountable to others, it turns out that morality does not rest solely on claims made by actual persons. In the example of someone stepping on someone's foot, we have a case of what Darwall calls a "bipolar obligation," in which there is a reciprocal relationship between two people. Person A makes a request of person B, assuming that B has the competence to recognize the legitimacy of the request and accede to it because of its legitimacy. Person A here has what Darwall calls individual authority, which is an authority grounded in the relation the two people have. There is a relation of moral obligation between two actual persons. Person B may be legitimately blamed for wronging A if B fails to respond to the request.

However, Darwall believes there is a difference between wronging a person who has individual authority and doing wrong simpliciter. All cases of wronging a person with individual authority are wrong simpliciter, but not all cases of doing wrong simpliciter are grounded in individual authority. ${ }^{5}$ Doing wrong simpliciter is conceptually linked to a demand that one would be blameworthy for not recognizing, but the demand is not one that must be made by anyone: "no moral obligation period, and so no bipolar obligations or moral claim right, can exist unless non-discretionary demands exist that do not depend on being made by anyone with the individual authority to make them." 6

These "non-discretionary demands" are made by everyone and no one, one might say. "Rather, when we blame someone, we add our voice to, or second, . . , a demand that we must presuppose is made of everyone by the moral community or a representative person

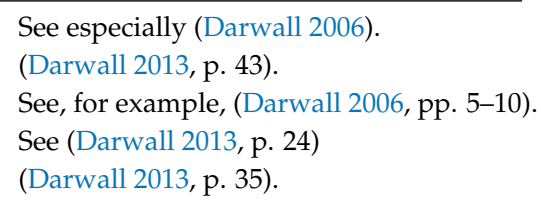


as such." ${ }^{\prime 7}$ Thus, there are many moral obligations that are not grounded in actual demands made by anyone. Darwall is quite explicit that "the moral community as I understand it is not any actual community composed of actual human beings," but rather is a "regulative ideal that we employ to make sense of our ethical thought and practice." ${ }^{\prime 8}$ I shall try to argue that the fictional character of the moral community poses problems for Darwall if he is understood as a constructivist.

\section{A Problem for Darwall}

Although Darwall does not claim that his view requires metaethical constructivism, even saying at one point that his view is compatible with a "recognitional realist" framework, his sympathies seem to be with a "procedural" constructivist view. ${ }^{9}$ I am going to assume in what follows that his proposal is intended as a form of constructivism. If one does not view Darwall as a constructivist, this could be considered a thought experiment to test the consistency of constructivism and Darwall's "juridical" view of morality. Constructivism, as I understand it, attempts to justify the objectivity of morality without positing the existence of "stance-independent" moral properties or facts. While Darwall draws on both Kantian and contractualist forms of constructivism, he seems to be offering yet another form by proposing that moral obligations are grounded in the claims human persons make on each other.

However, if Darwall is offering a form of constructivism, it is not a simple form in which morality is rooted in actual claims people make on each other since we have just seen that the claims that ground morality on his view include claims that may never actually be made, but that are in some way justified or warranted if they are made. The claims we make on each other as moral beings must be such that we can understand them as justified and such that we can expect that those we make claims on can recognize them as justified. Otherwise, a moral claim could not be distinguished from the demands of a bully. Obviously, justified or warranted claims are themselves normative in character and it looks as though these normative facts hold antecedently to any claims any actual person makes. A normative framework is thus presupposed by the account given of the claims we make on each other and is not simply the product of those claims. If I am justified when I ask a person who is standing on my foot to move his foot, then I have the moral standing to make the request, a legitimate right not to be stepped on. However, I must have this right even if I do not exercise it, which is a point Darwall supports. So far, I am not criticizing Darwall, but explaining what I take his view to be.

Therefore, it appears that even if some moral obligations are rooted in actual claims or demands, Darwall's account presupposes some other normative truths that do not rest on actual claims or demands since the account requires that we be able to recognize someone as having the authority or normative standing to make a demand. Furthermore, it also must be possible to say when the demands made by someone who has some moral authority are appropriate, given they possess that moral authority. Surely, having moral authority will be a normative matter and thus there must be some account of what it is to have such authority that is normative in character. It is clear that the account will not be one that rests the authority on making a demand because that would be circular. It is having the right kind of authority that makes it possible for one's demands to be moral demands. Merely making a demand is not sufficient to give one moral authority.

This is not necessarily an objection to a view such as Darwall's. There is no reason an account of one moral concept, obligation, cannot presuppose and make use of other normative concepts. A good example of this can be seen in Robert Adams' divine command theory of moral obligations (henceforth DCT). Adams responds to the Euthyphro objection to divine command theories by distinguishing the concept of moral obligation from that of

\footnotetext{
(Darwall 2013, p. 37).
}

(Darwall 2007).

9 See the brief discussion of metaethics in (Darwall 2006, pp. 293-97). However, in his "Reply to Korsgaard, Wallace, and Watson," Darwall claims his view does not require constructivism, though that is a view he would "happily" embrace (Darwall 2007, p. 64). 
the good. On his account, moral obligations are identical to God's expressed demands but they are not arbitrary, as Euthyphro objections claim is the case, because God is necessarily good and his commands are aimed at the good.

Adams' case is relevant to Darwall's view because, as Darwall himself acknowledges, there is a parallel between Darwall's view and a DCT. Both kinds of view see moral obligations as "what we are responsible or accountable for doing." ${ }^{10}$ Darwall sees early modern divine command theorists, such as Pufendorf and Locke, as holding that "the moral law implicates our accountability to God." ${ }^{11}$ He agrees with DCT theorists that morality requires accountability but says that "moral obligations concern our accountability to one another and ourselves as equal moral persons or members of the moral community." 12 The human moral community thus replaces God in Darwall's account.

This parallel between a DCT and Darwall's view suggests a possible problem with Darwall's view. A criticism often made against a DCT is usually called the "prior obligations" objection. ${ }^{13}$ This critic of a DCT argues that, even if God's commands are sufficient to create moral obligations, they are not necessary, because we would have an obligation to obey God prior to God giving any commands. Not all obligations are therefore created by divine commands. A parallel objection could be raised against Darwall's view, as follows: "Even if some of our moral obligations rest on the demands people make of each other, not all arise in this way, because there is a prior obligation to respect the legitimate demands of other people even when no demands have been made." It looks as if some obligations must already be in place for the demands humans make on each other to create obligations. Darwall, I take it, understands the necessity of this, and that is why he proposes that, in addition to bipolar obligations between actual individuals, there are moral obligations that exist independently of the claims made by actual persons. These are the claims that people could make as representatives of the ideal "moral community."

One may, at this point, wonder what the problem is. After all, the view that there are such obligations is an explicit part of Darwall's view, not an objection to it. My answer is that the distinction between such standing obligations and those created by actual demands is not itself a problem. I agree that some such distinction is necessary to distinguish the bully from someone making a valid moral claim. The problem I want to raise is whether, if Darwall is understood as a constructivist, he has the resources to make sense of the distinction, while continuing to hold that morality is "second-personal" in nature. Are the "prior obligations" that hold antecedently to any actual claims made by actual persons something that the constructivist can explain? Can "the moral community," understood as a "regulative ideal," do the job? If not, then there might seem to be moral obligations that are not second-personal in nature after all. ${ }^{14}$

Darwall could evade the problem by retreating to a weaker position, which claims that the demands made by humans are not the basis of all moral obligations, but just some obligations. ${ }^{15}$ In a similar way, the proponent of a DCT might retreat to the weaker position that God's commands are sufficient for moral obligations, though not necessary. However, such a response seems more plausible for Adams than for Darwall, at least if Darwall is understood as a metaethical constructivist rather than a moral realist since the proponent of a DCT who follows Adams is clearly a moral realist and, thus, could (and does) recognize objective moral truths that are independent of the demands of any person, human, or divine being. Adams is not a voluntarist who tries to ground all moral truths in acts of

\footnotetext{
(Darwall 2013, p. 179)

(Darwall 2013, p. 179).

(Darwall 2013, p. 179)
}

3 For a clear account of the kind of objection to a DCT, see (Wainwright 2005, pp. 80-83).

14 Darwall, in fact, might be open to such a qualified view of not all moral obligations being grounded in second-personal reasons. At one point he says that there might be moral obligations that are "not relational or bi-polar," such as those to take care of the environment. See (Darwall 2007, p. 61).

15 There is another response I will not discuss here, one which could be used both by the advocate of a DCT and by Darwall, in which it is argued that the "prior obligations" are not true obligations, but just good reasons to fulfill the legitimate demands of others. This response still would leave the position vulnerable to the problem discussed below. 
willing. In fact, Adams roots his divine command account of moral obligation in a Platonic theory of the good that the theory of obligation presupposes.

If Darwall is a constructivist, however, it is not clear that a similar move is open to him. The set of moral facts that hold antecedently to the demands humans make on each other seems to be facts that are independent of any actual demands. ${ }^{16}$ Darwall wants these facts to be derived from an ideal moral community, but there are, I believe, several problems in trying to see such obligations as arising in this manner.

One worry is that Darwall's moral community faces its own Euthyphro problem. Can we really say that what makes a moral obligation to be a moral obligation is that it is a claim or demand that could be made by someone as a representative of the moral community? Or is it not rather the case that it is because the claim is already moral in character that someone who makes it is representing the moral community? The former alternative appears to lead to the same kind of arbitrariness that those who press a Euthyphro problem against a DCT claim will follow from a DCT, while the latter alternative seems to imply that moral principles are antecedently true independently of any human claim.

One may here respond on Darwall's behalf that constructivism does not assume that moral obligations are constructed by actual humans, but are principles that reasonable human persons would follow. Thus, the "actors" or "contractors" who construct morality can be hypothetical or ideal, just as is the case with Darwall's moral community.

However, I believe there are problems that lurk for constructivism at just this point and that those problems may infect Darwall's view if it is understood as a form of constructivism. It is not clear that actual obligations can be derived from nonactual persons or communities. Suppose, for example, that a person in my situation who was perfectly rational would promise to make a donation to some worthy cause, such as alleviating climate change. If such an idealized version of myself existed, that person would thereby acquire an obligation to do this. It is not at all clear that the fact (if it is a fact) that this (nonexistent) person would make such a promise and thus have an obligation means that I am actually obligated to make such a donation (even if it were a good thing for me to do, I would not be obligated to do it since I have not promised to do so).

Another problem may lie in the indeterminate character of what the "moral community" would do. Is there a fact of the matter as to what representatives of the moral community would claim from each other? Just as it is sometimes claimed that Kant's categorical imperative is too abstract and formal to give rise to determinate moral principles, it may be that the idea of the "moral community" is too abstract and formal to give rise to determinate moral obligations.

Yet another problem stems from the identity of the moral community. How does one know when one is representing the moral community? How do humans achieve this status? Which claims that humans make are justified as moral? Clearly, many of the claims that humans make on each other are not morally valid claims. If we say that the claims humans make on each other are morally valid only if they are in accord with claims that are morally justified, then it looks as if those claims must be antecedently justified. One becomes a representative of the moral community by making claims that are morally justified; it is not the case that claims are morally justified because they are made by representatives of the moral community. The parallel with the Euthyphro objections to a DCT should be clear.

\section{Should Darwall Embrace Moral Realism?}

Would it be possible for Darwall to reject constructivism and accept a moral realist framework? Yes, but this would represent a shift that seems inconsistent with some of the motivation for the view. A common theme among constructivists is that moral truths do not exist as independent facts that the human will must simply recognize. Rather, moral facts are in some way constituted by the human will. Moral realism is seen as a threat to the rational autonomy of humans. In a similar spirit, Darwall says that "when you and I

16 There is a nice discussion of this problem in (Zilberman 2017). Zilberman calls this problem in Darwall the "antecedent problem." 
make a claim to autonomy that we take to be rooted in the dignity of persons, therefore, we presuppose that we are bound by practical laws and reasons that are valid, not by virtue of any 'object' of volition, whether the value of any outcome or of any act considered in itself."17

Could the reference to "dignity" above as the "root" of the claim to autonomy help? Dignity might be taken to be a kind of intrinsic value that humans have. On this view, the "authority" that humans have to make justified claims on each other is derived from this value and can be reasonably exercised only if this value is respected. However, this kind of appeal to intrinsic value seems to presuppose moral realism. On such a view, the objective value gives rise to the moral status, while the constructivist wants the moral status to be in some way the product of our activity.

There is another problem that a shift to a moral realist framework might solve. I noted above that it is often argued that constructivist-type views that base morality on rational agency are too formal and abstract to provide substantive moral content. The contemporary Kantian Christine Korsgaard recognizes this problem by admitting that the categorical imperative by itself is too formal to give us concrete moral guidance and needs to be supplemented by what she calls a "principle of identity," since "a view of what you ought to do is a view of who you are." 18

A similar problem faces Darwall's form of constructivism. It is far from clear that we can determine what demands humans are justified in making on each other merely by seeing them as equal participants in the moral community. Darwall says that the authority a free, rational agency is "bound to recognize" stems from "whatever authority one is committed to in making and considering claims in the first place." ${ }^{\prime 19}$ Even if this is so, it is not easy to see how one might go from recognizing this authority to deciding what particular claims are justified.

Darwall tries to show that at least one substantive moral principle can be derived merely from recognizing other humans as moral agents. This principle is that we must recognize and value others' autonomy. Darwall supports the value of autonomy by giving the example of parents who pressure a middle-aged child to eat broccoli because it is good for her, even though she does not like broccoli. ${ }^{20}$ This example has force; most would agree that it is wrong for parents to try to control the choices of a middle-aged child in this way. However, even if this is so, it does not mean that autonomy's value is unlimited, or that it is the only relevant factor. Suppose the daughter is an alcoholic, and she wants to drink alcohol, even though her liver is failing, and her life is at stake. In that case, her autonomy surely must be lower in value than saving her life. Paternalism is sometimes objectionable, but it also sometimes appears to be justified. The value of autonomy is not absolute, and a reasonable person would have to balance that value against other values. Without a realist moral framework, it is very hard to see how Darwall can derive concrete guidance for dealing with actual moral situations. ${ }^{21}$

Consider again the parallel between an Adams-type DCT and Darwall's view. On the DCT, God gives us obligations, but there must be a framework of values that undergirds his authority to do this. Similarly, perhaps humans create obligations by making demands or claims on each other. However, just as in the case of a DCT, this ability humans have to create obligations by making demands on each other rests on a framework of antecedent

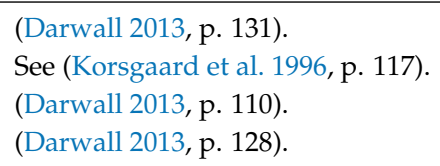

21 In (Darwall 2006, pp. 300-20), Darwall suggests that this problem might be solved via contractualism, with his own view providing a kind of foundation for the contractualist view. I think this move is dubious for several reasons; I doubt that a view like Darwall's is consistent with most forms of contractualism. However, this is a subject for another paper. 
values. ${ }^{22}$ However, such a view would not be a form of constructivism; it would require a commitment to moral realism in the end.

\section{Does Darwall Need God as Part of the Story for His Account to Work?}

Given a realist framework, which undergirds the authority humans have to make justified demands on each other, it does look like humans could generate some moral obligations. However, if one wants to hold firmly to a "juridical" view of moral obligations, which grounds all of them in the claims or demands persons make on each other, it is not clear that idealized demands, which are demands that one makes as a "representative of the moral community," will do the job since such hypothetical demands look just like timeless moral truths of the sort that non-natural realists accept. They are not actual demands, but rather demands that would be reasonable to accept if they were made.

At this point, a DCT actually has an advantage over Darwall's view. The DCT grounds moral obligations in the justified demands God makes on humans. The proponent of a DCT takes God to be an actual being, and the demands or commands that are made by God are not just hypothetical but actual. To see the advantage of a DCT, compare a DCT to an "ideal observer" theory of ethics. Ideal observer theory identifies moral obligations with the judgments of an ideal observer, which is a being who is fully knowledgeable and impartial. However, it is not clear why an actual human should care about what judgments such an ideal observer would make (assuming that such a being could make such judgments and we would know what they are). Why should I care about the judgments of a nonexistent being? However, if God actually exists, God's judgments might matter greatly. For example, it may be argued that humans owe a great debt of gratitude to God as the creator of every good we have, or it might be argued that our ultimate happiness is linked to a loving relationship with God.

In fact, a DCT might provide exactly what Darwall's view needs. The demands that Darwall says we make as "representatives of the moral community" might just be the demands that God wills for us to make on each other. Darwall would then have the antecedent moral truths his theory requires. There would be actual demands, made by an actual person, that undergird the ideal demands we should make on each other, and we would be properly representing the moral community when our demands align with those God wills us to make.

I believe that much of what Darwall says about divine command theory is correct and valuable. For example, he claims that for God's commands to create moral obligations, it would have to be the case that God has authority that human subjects can themselves recognize as legitimate, such that if God sanctions humans for disobeying those commands, God would have to assume that reasonable humans would themselves agree that they deserve the sanctions. Points such as this show that a viable DCT must be rooted in an underlying framework of normative truths that are independent of God's will. However, this is exactly what a DCT such as that provided by Adams offers. Darwall often labels a DCT as a form of "voluntarism." This may, however, be misleading, for if God's commands are constrained by his understanding of the good, it is not clear how much discretion, if any, God has over what he commands. ${ }^{23}$

The theistic framework sketched here fits well with the moral realism Darwall's view seems to need. The dignity or intrinsic value humans have, which the view requires, can be explained by the fact that humans are creatures of God and are made in God's image. ${ }^{24}$

22 On this point Watson's "Morality as Equal Accountability" is helpful again, in suggesting that Darwall's account of the right is too loosely connected to the good, specifically the good life for humans. See (Watson 2007, pp. 46-50).

23 (Evans 2013) distinguishes two aspects of a DCT, which he terms the "modal status thesis" and the "divine discretion thesis." Evans argues that only the former is actually essential to a DCT, which means that nonvoluntaristic forms of a DCT are possible. See pp. 34-37.

24 Here, I shall not attempt the enormous task of explaining how God might be the basis of human dignity or arguing that a religious basis for this dignity is superior to secular accounts. There is an enormous literature on this topic that I cannot do justice to here, but here are a couple of good starting places to explore the issue: For an attempt to argue that human dignity requires a religious foundation, see (Wolterstorff 2008, pp. 316-19). For a good discussion of alternative ways of conceiving of dignity, including secular alternatives, see again Ariel Zilberman (2017) "Two Second-Personal Conceptions of the Dignity of Persons." The Zilberman article is particularly valuable since it focuses on Darwall. 
This is not a voluntarist framework. Rather, God himself possesses supreme value, and creatures made in his image would participate in that value or share in it because humans can mirror or image God. Humans may indeed create obligations by making demands on each other and holding each other accountable, but they can do that because of the moral status they possess.

Funding: I wish to thank the Templeton Religion Trust, which funded this research by Grant 0171, on "The Virtue of Accountability." The views expressed in the article do not necessarily reflect the views of the Templeton Religion Trust.

Institutional Review Board Statement: Not applicable.

Informed Consent Statement: Not applicable.

Data Availability Statement: Not applicable.

Conflicts of Interest: The author declares no conflict of interest.

\section{References}

Darwall, Stephen. 2006. The Second-Person Standpoint: Morality, Respect, and Accountability. Cambridge: Harvard University Press.

Darwall, Stephen. 2007. Reply to Korsgaard, Wallace, and Watson. Ethics 118: 64. [CrossRef]

Darwall, Stephen. 2013. Morality, Authority, and Law. Oxford: Oxford University Press.

Evans, C. Stephen. 2013. God and Moral Obligation. Oxford: Oxford University Press.

Korsgaard, Christine M., Christine Marion Korsgaard, Christine Marion Korsgaard Korsgaard, Gerald Allan Cohen, Raymond Geuss, Thomas Nagel, and Bernard Williams. 1996. The Sources of Normativity. Cambridge and New York: Cambridge University Press. Wainwright, William. 2005. Religion and Morality. Aldershot: Ashgate Publishing.

Watson, Gary. 2007. Morality as Equal Accountability: Comments on Stephen Darwall's The Second-Person Standpoint. Ethics 118: 37-51. [CrossRef]

Wolterstorff, Nicholas. 2008. Justice: Rights and Wrongs. Princeton: Princeton University Press.

Zilberman, Ariel. 2017. Two Second-Personal Conceptions of the Dignity of Persons. European Journal of Philosophy 25: 921-43. [CrossRef] 